\title{
The Impact of Human Mobility on Regional and Global Efforts to Control HIV Transmission
}

\author{
Emily A. Eshraghian ${ }^{1}\left(\mathbb{D}\right.$, Sepideh N. Ferdos ${ }^{1}$ and Sanjay R. Mehta ${ }^{2,3, *(D)}$ \\ 1 Department of Family Medicine and Public Health, University of California San Diego, La Jolla, \\ CA 92093, USA; eeshragh@ucsd.edu (E.A.E.); sferdos@ucsd.edu (S.N.F.) \\ 2 Departments of Medicine and Pathology, University of California San Diego, La Jolla, CA 92161, USA \\ 3 Department of Medicine, San Diego Veterans Affairs Medical Center, San Diego, CA 92161, USA \\ * Correspondence: srmehta@ucsd.edu; Tel.: +1-858-642-3175
}

Received: 6 November 2019; Accepted: 2 January 2020; Published: 6 January 2020

check for updates

\begin{abstract}
HIV prevention and control methods are implemented on different scales to reduce the spread of the virus amongst populations. However, despite such efforts, HIV continues to persist in populations with a global incidence rate of 1.8 million in 2017 alone. The introduction of new infections into susceptible regional populations promotes the spread of HIV, indicating a crucial need to study the impact of migration and mobility on regional and global efforts to prevent HIV transmission. Here we reviewed studies that assess the impact of human mobility on HIV transmission and spread. We found an important role for both travel and migration in driving the spread of HIV across regional and national borders. Combined, our results indicate that even in the presence of control and preventive efforts, if migration and travel are occurring, public health efforts will need to remain persistent to ensure that new infections do not grow into outbreaks.
\end{abstract}

Keywords: HIV; transmission networks; molecular epidemiology; prevention and care; disease surveillance; public health response

\section{Introduction}

Globalization and international migration are important factors that facilitate the spread of infectious diseases [1-3]. Human mobility promotes the movement of diseases and the establishment of epidemics in susceptible populations, leading to outbreaks of emerging and reemerging infectious diseases [1,4]. More specifically, human mobility has been identified as a key driver in the diffusion of the HIV epidemic within nations [5,6] and around the world [7,8]. Surveillance and understanding of human migration trends is important when monitoring the epidemiology of HIV in order to better understand exposure, which modifies infection rates among populations [1,9].

Communities around the globe have varying levels of prevention and control resources for reducing the transmission of HIV. Risk for acquisition and transmission is impacted by social, structural, and population level factors $[7,10]$. These elements contribute to local risk contexts that lead to variations in the global spread of the virus. Such risk contexts can also be impacted by the presence or absence of appropriate prevention tools and services throughout communities [7], and may be further influenced by human mobility [11].

The HIV epidemiological curve is shaped by an increasingly mobile global population, and such mobility may exacerbate the risk of HIV transmission [12]. To prevent dissemination of HIV, some countries restrict entry of HIV positive travelers [13]. However, in this era where HIV has become an easily treatable chronic disease and in which there is increasing global interconnectedness, these approaches impinge on human rights. Still, without understanding the role of mobility and migration in local HIV epidemics, the effectiveness of prevention and control efforts designed to lower 
HIV incidence are limited [14]. In this perspective paper, we highlight the impact of human migration and mobility on existing prevention efforts in the context of HIV dissemination.

\section{Methods}

To allow the incorporation of relevant literature as evidence for this perspective paper, searches of PubMed and Google Scholar were conducted in May 2019. The following limits were applied: Published online and in the English language between 1998 and 2019. Appropriate synonyms and free terms were used in each database search. A combination of the following search terms were used: Communicable disease, and/or migration, and/or HIV, and/or AIDS, and/or transmission, and/or transmission network, and/or importation, and/or exportation, and/or spatial clustering, and/or prevention, and/or molecular epidemiology, and/or viral diseases, and/or border surveillance, and/or spatial clustering, and/or transmission route(s), and/or travel, and/or surveillance, and/or control and/or epidemic, and/or outbreak, and/or viral migration. Further, only empirical and observational studies are included.

After database searches, we complied a total of 390 studies. Eighty-four duplicates were removed, leaving us with 306 studies to screen. Since our goal was to evaluate the impact of migration and mobility on HIV epidemiology, an additional 323 studies were eliminated upon review of titles and abstracts. Upon assessment of the full-text of the remaining 37 articles, 16 articles were eliminated based on lack of access to full-text or irrelevance to our main aims. The final 21 studies included as evidence in our paper are summarized in Table 1.

\section{The Role of Cross-Border Coordination in Infection Control}

Infectious diseases and particularly viral pathogens have long been associated with spread due to human mobility, even in the presence of effective preventive and control efforts. In the following section, we outline pertinent examples of viral transmission impacted by mobility. The measles outbreak in 2019 demanded the attention of the entire world. Although a vaccine preventable disease, measles incidence grew rapidly across the globe in 2019 [15]. A review of measles in developed countries, including the Americas, Europe, and Australia found that $100 \%$ of measles cases were imported or import-related [16], Interestingly, in another study, the risk of importing measles was higher among indigenous travelers compared to immigrants [17], suggesting that mobility (i.e., travel) and not just migration is important in the spread of disease.

Similarly, the Ebola outbreak in west Africa in 2014-2016 spread rapidly regionally with movement of individuals between rural and urban areas in Sierra Leone, Guinea, and Liberia [14]. This led the international community to restrict air travel from the area, which modeling studies showed was vital for preventing dissemination of Ebola to the rest of the world [18]. However, even with this, between November 10, 2014, and July 12, 2015, the US Centers for Disease Control and Prevention (CDC) made 2374 notifications of travelers who were monitored by US health departments because they had been to an Ebola-affected country in West Africa [19].

In contrast to measles and Ebola, transmitted via airborne and contact routes respectively, HIV is transmitted through contact with infected body fluids. Therefore, risk factors for HIV transmission are predominantly of a behavioral nature. While HIV is not as directly impacted by mobility as measles and Ebola, mobility and migration is often linked with behavioral mechanisms that include increased risk taking, which can impact HIV transmission [20]. For example, participation in injection drug-use [21], transactional sex [20], and rape [22] are more common among mobile populations, all of which are risks for HIV transmission. Furthermore, the latency period before clinical symptoms also allows a greater window of travel while infectious. Human migration from the displacement and movement of large refugee populations arising from areas of conflict, war, or economic hardship, also can increase risk of HIV transmission and acquisition $[5,11,12,20]$. Globalization itself has also historically been shown to play a crucial role in the spread and rate of infectious diseases among different populations [23,24]. In the United States, efforts focused on prevention of disease transmission and dissemination have 
produced substantial successes. Incident cases of HIV have been reduced through advancements in HIV testing technologies and implementation of evidence-based behavioral change interventions, surveillance of blood supply, condom use, needle exchange programs, and pre-exposure prophylaxis, among other preventive interventions [25]. Despite efforts towards control, prevention, and treatment methods for HIV through the implementation of international mechanisms and funds directed towards lower-income countries, HIV incidence continues to be unacceptably high [26].

\section{Human Mobility and HIV}

Historical lessons of responses to the HIV epidemic have illustrated that the following conditions are essential for effective control and prevention: Coordinated national planning efforts, implementation of evidence-based strategies that correspond to the population's needs, and an environment conducive to the social and political inclusion of people living with and at risk of HIV [27]. In order to implement effective infection control and prevention efforts, it is vital to understand the dynamics of HIV transmission across regional and international borders and how these epidemics are linked [28]. To demonstrate the need of coordinating public health efforts internationally, we have formulated a volume of literature that indicates the value of and suggests the urgency of intra and international coordination efforts across borders in order to optimize infection control. Table 1 characterizes a collection of studies that place a particular emphasis on enjoining efforts across borders to recognize groups of individuals who are at an increased risk of contracting the disease. We use this literature to highlight that HIV prevention measures on one side of a border may provide only limited benefit if they are not matched across borders. It is important to note that the lack of standards in inferring linked HIV infections make it difficult to compare and contrast HIV transmission clusters across studies.

Table 1. Summary of articles reviewed regarding human mobility and HIV.

\begin{tabular}{|c|c|c|c|}
\hline Author (Year) & Relevant Aims & Results & Comments/Notes on Migration \\
\hline $\begin{array}{l}\text { Aibekova } \\
(2018)[29]\end{array}$ & $\begin{array}{l}\text { Analyze the distribution of } \\
\text { HIV-1 subtype A in thirteen } \\
\text { former Soviet Union countries }\end{array}$ & $\begin{array}{l}\text { HIV-1 subtype A clusters } \\
\text { are intermixed }\end{array}$ & $\begin{array}{l}\text { Intermixed clusters indicate a possible role of } \\
\text { migration-associated HIV transmission }\end{array}$ \\
\hline $\begin{array}{l}\text { Castley } \\
(2017)[30]\end{array}$ & $\begin{array}{l}\text { Determine HIV-1 subtype } \\
\text { distribution and phylogenetic } \\
\text { structure in Australia between } \\
2005 \text { and } 2012\end{array}$ & $\begin{array}{l}\text { HIV-1 epidemic in Australia is } \\
\text { characterized by an increasing } \\
\text { prevalence of non-B subtype } \\
\text { infections and an overall expanding } \\
\text { subtype diversity }\end{array}$ & $\begin{array}{l}\text { Migration and overseas travel are potentially } \\
\text { associated with the increasing prevalence and } \\
\text { subtype diversity of infections }\end{array}$ \\
\hline $\begin{array}{l}\text { Chaillon } \\
\text { (2017) [31] }\end{array}$ & $\begin{array}{l}\text { Understand regional HIV } \\
\text { epidemics, the viral } \\
\text { transmission links between } \\
\text { these epidemics, and risk groups } \\
\text { across the Mesoamerican region }\end{array}$ & $\begin{array}{l}\text { Infrequency of international clusters } \\
\text { suggests moderate migration } \\
\text { between HIV epidemics of various } \\
\text { Mesoamerican countries, but } \\
\text { analyses indicate that Central and } \\
\text { Southern Mexico and Belize were } \\
\text { significant sources of HIV } \\
\text { transmission throughout } \\
\text { Mesoamerica } \\
\text { Evidence of significant viral } \\
\text { migration within Mexico }\end{array}$ & $\begin{array}{l}\text { Human migration or travel is assumed to be the } \\
\text { cause of transmission links among individuals } \\
\text { from different nations } \\
\text { Such transmission links may impact the overall } \\
\text { epidemic by bridging susceptible populations } \\
\text { and resulting in onward transmission }\end{array}$ \\
\hline $\begin{array}{l}\text { de Pina-Araujo } \\
\text { (2015) [32] }\end{array}$ & $\begin{array}{l}\text { Reconstruct the phylogenetic } \\
\text { relationship, onset date, and } \\
\text { dissemination routes of the } \\
\text { HIV-1 subtype G clades present } \\
\text { throughout Angola, Cape Verde, } \\
\text { and Portugal }\end{array}$ & $\begin{array}{l}\text { HIV-1 subtype G likely originated in } \\
\text { Central Africa and dissemination to } \\
\text { Western and West-Central Africa } \\
\text { occurred about a decade later }\end{array}$ & $\begin{array}{c}\text { The local dissemination of HIV-1 subtype G } \\
\text { infections in Cape Verde and Portugal are shaped } \\
\text { by historical and ongoing movement of human } \\
\text { populations between Angola, Cape Verde, } \\
\text { and Portugal }\end{array}$ \\
\hline $\begin{array}{c}\text { Leroy } \\
(2008)[33]\end{array}$ & $\begin{array}{l}\text { To assess the frequency of } \\
\text { travel-related illnesses among } \\
\text { ill-returned travelers in one } \\
\text { infectious diseases department } \\
\text { in France }\end{array}$ & $\begin{array}{l}\text { Of the } 265 \text { diagnoses made in } \\
\text { travelers who returned with illness, } \\
\text { there were } 6 \text { incident HIV cases }\end{array}$ & $\begin{array}{l}\text { Travelers are susceptible to infections, which } \\
\text { have the potential to be disseminated when they } \\
\text { return to their home country }\end{array}$ \\
\hline $\begin{array}{l}\text { Magiorkinis } \\
(2016)[34]\end{array}$ & $\begin{array}{l}\text { Clarify the global routes of the } \\
\text { HIV epidemic \& understand the } \\
\text { influence of human activity on } \\
\text { HIV dissemination }\end{array}$ & $\begin{array}{l}\text { The American continent and the } \\
\text { Caribbean drove the epidemic } \\
\text { outward to other geographic } \\
\text { locations through an initial random } \\
\text { migration event and further } \\
\text { subsequent migrations globally }\end{array}$ & $\begin{array}{l}\text { Dissemination of HIV through specific migration } \\
\text { routes are consistent with geopolitical factors } \\
\text { that affected human activities during the last } \\
50 \text { years, including migration. This evidence } \\
\text { supports the argument that epidemic control } \\
\text { policies should be implemented at global scales }\end{array}$ \\
\hline
\end{tabular}


Table 1. Cont.

\begin{tabular}{|c|c|c|c|}
\hline Author (Year) & Relevant Aims & Results & Comments/Notes on Migration \\
\hline $\begin{array}{c}\text { Mehta } \\
\text { (2015) [28] }\end{array}$ & $\begin{array}{l}\text { Characterize HIV transmission } \\
\text { networks in the San } \\
\text { Diego-Tijuana region using HIV } \\
\text { sequence and demographic data }\end{array}$ & $\begin{array}{c}\text { Persistent bidirectional cross-border } \\
\text { HIV transmission link groups across } \\
\text { the border }\end{array}$ & $\begin{array}{l}\text { Viral migrations of HIV across the border } \\
\text { stemmed from recently formed transmission } \\
\text { clusters, which may be indicative of ongoing } \\
\text { cross-border transmission } \\
\text { The HIV epidemic is relevant and important to } \\
\text { at-risk communities on both sides of a border }\end{array}$ \\
\hline $\begin{array}{l}\text { Paraskevis } \\
(2009)[35]\end{array}$ & $\begin{array}{l}\text { Infer the migration history of } \\
\text { HIV- } 1 \text { subtype B among } 17 \\
\text { countries in Europe }\end{array}$ & $\begin{array}{l}\text { In most countries, the epidemic was } \\
\text { introduced by multiple sources and } \\
\text { subsequently spread within local } \\
\text { networks; considerable differences } \\
\text { between countries are present }\end{array}$ & $\begin{array}{l}\text { Considering the pathways of viral spread } \\
\text { together with the geographic distributions of } \\
\text { viral phylogenies, intervention strategies should } \\
\text { also address mobile populations }\end{array}$ \\
\hline $\begin{array}{l}\text { Paraskevis } \\
(2017)[36]\end{array}$ & $\begin{array}{l}\text { Estimate the proportion of } \\
\text { postmigration HIV-1 } \\
\text { transmissions among migrants } \\
\text { who inject drugs \& infer } \\
\text { whether postmigration } \\
\text { transmission occurs more } \\
\text { frequently through contacts } \\
\text { with other migrants who inject } \\
\text { drugs or through contacts with } \\
\text { Greek injection drug users }\end{array}$ & $\begin{array}{l}\text { A majority of HIV-1 infections in } \\
\text { migrant injection drug users were } \\
\text { acquired after migrants moved } \\
\text { to Greece } \\
\text { Transmission of HIV-1 occurs more } \\
\text { frequently through contacts } \\
\text { between migrants }\end{array}$ & $\begin{array}{c}\text { Migrant populations are a priority for targeting } \\
\text { HIV prevention efforts, as there exists significant } \\
\text { transmission networking among migrants } \\
\text { subsequent to their migration }\end{array}$ \\
\hline $\begin{array}{l}\text { Paraskevis } \\
(2019)[37]\end{array}$ & $\begin{array}{c}\text { Identify and characterize } \\
\text { molecular transmission clusters } \\
\text { using molecular phylogenetic } \\
\text { analyses \& examine impact of } \\
\text { clinical and demographic factors } \\
\text { on regional phylogenetic } \\
\text { clustering }\end{array}$ & $\begin{array}{l}\text { Local populations are more likely to } \\
\text { be infected within their own country, } \\
\text { as reflected by the finding that } \\
\text { subtype B infections have a higher } \\
\text { probability of belonging to a } \\
\text { molecular transmission cluster }\end{array}$ & $\begin{array}{l}\text { Growth of regional HIV-1 epidemics is mainly } \\
\text { associated with recent molecular transmission } \\
\text { clusters compared to established cases }\end{array}$ \\
\hline $\begin{array}{l}\text { Parczewski } \\
\text { (2014) [38] }\end{array}$ & $\begin{array}{l}\text { Investigate the HIV sequence } \\
\text { variability among } \\
\text { travel-associated cases with } \\
\text { reported infection outside of } \\
\text { Poland and trace the country of } \\
\text { origin where infected was } \\
\text { transmitted }\end{array}$ & $\begin{array}{l}\text { Import of HIV-1 non-B subtype } \\
\text { variants, including recombinant } \\
\text { viral forms, is frequent } \\
\text { among travelers }\end{array}$ & $\begin{array}{l}\text { Introduction of HIV into the local population by } \\
\text { immigrating travelers may contribute to an } \\
\text { increasing number of circulating variants and } \\
\text { viral diversification, while posing a risk of } \\
\text { exponential infection spread in the population }\end{array}$ \\
\hline $\begin{array}{c}\text { Rasmussen } \\
(2018)[40]\end{array}$ & $\begin{array}{l}\text { Quantify the contribution of } \\
\text { local viral transmission versus } \\
\text { external introductions to overall } \\
\text { HIV incidence }\end{array}$ & $\begin{array}{l}\text { The majority of samples are } \\
\text { interspersed throughout clades } \\
\text { composed predominantly of } \\
\text { external samples, indicating that } \\
\text { many independent introduction } \\
\text { events have occurred into the local } \\
\text { population from elsewhere }\end{array}$ & $\begin{array}{c}\text { External viral introductions play a large role in } \\
\text { sustaining high HIV incidence, which confirms } \\
\text { the important role of human mobility in } \\
\text { HIV dissemination }\end{array}$ \\
\hline $\begin{array}{l}\text { Schlagenhauf } \\
\text { (2015) [41] }\end{array}$ & $\begin{array}{l}\text { Assess available European } \\
\text { surveillance data for } \\
\text { travel-related illnesses to profile } \\
\text { imported infections, track } \\
\text { trends, identify risk groups, and } \\
\text { assess the usefulness of } \\
\text { pre-travel advice }\end{array}$ & $\begin{array}{l}\text { Migration within Europe was } \\
\text { associated with HIV/AIDS infections, } \\
\text { among several other infections } \\
\text { Pre-travel consultation was } \\
\text { associated with significantly lower } \\
\text { proportionate morbidity ratios for } \\
\text { HIV/AIDS }\end{array}$ & $\begin{array}{c}\text { The profile of travel-related infections varies } \\
\text { according to the traveler type, migration trends, } \\
\text { and the purpose of travel } \\
\text { Pre-travel advice is useful for reduction of } \\
\text { proportional morbidity with several infections, } \\
\text { including HIV/AIDS }\end{array}$ \\
\hline $\begin{array}{c}\text { Sinka } \\
\text { (2003) [42] }\end{array}$ & $\begin{array}{l}\text { Describe the epidemiology of } \\
\text { HIV infection acquired in Africa } \\
\text { and among African } \\
\text { communities in the United } \\
\text { Kingdom }\end{array}$ & $\begin{array}{l}\text { African-acquired HIV infections } \\
\text { diagnosed in the United Kingdom } \\
\text { by } 2001 \text { make up about } 21 \% \text { of all } \\
\text { reported infections and continue to } \\
\text { increase rapidly specific to different } \\
\text { regions within Africa }\end{array}$ & $\begin{array}{l}\text { Early diagnosis of HIV infection is an important } \\
\text { component of intervention to prevent } \\
\text { transmission, but migration, diagnosis of } \\
\text { long-standing infection, and incident cases are } \\
\text { potential influences that should be accounted for } \\
\text { in order to lower the burden of HIV infection }\end{array}$ \\
\hline
\end{tabular}


Table 1. Cont.

\begin{tabular}{|c|c|c|c|}
\hline Author (Year) & Relevant Aims & Results & Comments/Notes on Migration \\
\hline $\begin{array}{c}\text { Takebe } \\
\text { (2014) [44] }\end{array}$ & $\begin{array}{l}\text { Explore possible linkages } \\
\text { between the HIV epidemics in } \\
\text { East Asia and those in the rest of } \\
\text { the world }\end{array}$ & $\begin{array}{l}\text { HIV subtype B variant that was } \\
\text { common among Japanese MSM was } \\
\text { detected worldwide, suggesting that } \\
\text { specific subgroups may have been } \\
\text { circulating locally before } \\
\text { disseminating to other countries } \\
\text { through global contact networks }\end{array}$ & $\begin{array}{l}\text { Viral migration is bidirectional, as seen by trends } \\
\text { in countries whose HIV epidemics have been } \\
\text { considered a result of imported viruses, but have } \\
\text { demonstrated exportation of specific } \\
\text { HIV lineages }\end{array}$ \\
\hline $\begin{array}{c}\text { von Wyl } \\
\text { (2011) [45] }\end{array}$ & $\begin{array}{l}\text { Examine the possibility of } \\
\text { locating evidence for ongoing } \\
\text { non-B transmission in } \\
\text { Switzerland by identifying } \\
\text { possible transmission pairs }\end{array}$ & $\begin{array}{l}\text { Migration has a greater contribution } \\
\text { to newly diagnosed non-B subtype } \\
\text { HIV-1 infections among Africans } \\
\text { compared to domestic transmission }\end{array}$ & $\begin{array}{c}\text { Migration and domestic transmission both play a } \\
\text { role in the epidemiology and transmission of } \\
\text { non-B subtype HIV-1 } \\
\text { A fraction of all non-B infections diagnosed in } \\
\text { Switzerland could be prevented by local } \\
\text { interventions } \\
\text { To contain HIV dissemination, awareness should } \\
\text { be raised among immigrants and Swiss } \\
\text { individuals with partners from countries where } \\
\text { HIV is endemic }\end{array}$ \\
\hline $\begin{array}{c}\text { Wang, X } \\
\text { (2015) [46] }\end{array}$ & $\begin{array}{l}\text { Determine efficiency of using } \\
\text { inferred network characteristics } \\
\text { to target prevention } \\
\text { interventions }\end{array}$ & $\begin{array}{l}\text { The efficiency of targeting } \\
\text { prevention efforts according to the } \\
\text { number of network connections was } \\
\text { higher than if not targeting } \\
\text { such efforts }\end{array}$ & $\begin{array}{l}\text { Using network connectivity information to } \\
\text { administer preventive treatment may be an } \\
\text { efficient way to deliver prevention interventions } \\
\text { and will aid in lowering rates of } \\
\text { HIV dissemination }\end{array}$ \\
\hline $\begin{array}{c}\text { Wang, Y } \\
\text { (2015) [47] }\end{array}$ & $\begin{array}{l}\text { Assess HIV-1 prevalence and } \\
\text { subtype distribution of entry } \\
\text { travelers at the HeKou port, a } \\
\text { major land port between Yunnan } \\
\text { and Vietnam, from } 2003 \text { to } 2012\end{array}$ & $\begin{array}{l}\text { Trends of the HIV-1 molecular } \\
\text { epidemiology among cross-border } \\
\text { travelers within the HeKou port } \\
\text { highlights the importance of } \\
\text { continually monitoring new trends } \\
\text { of the HIV epidemic and emerging } \\
\text { novel recombinants, particularly } \\
\text { among migrating populations }\end{array}$ & $\begin{array}{l}\text { To prevent transmission of infectious pathogens, } \\
\text { extended epidemiologic surveillance should be } \\
\text { implemented at borders, especially where } \\
\text { cross-border populations have particularly } \\
\text { high mobility }\end{array}$ \\
\hline $\begin{array}{l}\text { Wertheim } \\
\text { (2014) [48] }\end{array}$ & $\begin{array}{l}\text { Analyze global HIV-1 } \\
\text { transmission patterns through } \\
\text { construction of HIV-1 } \\
\text { transmission clusters using only } \\
\text { close genetic links to identify } \\
\text { potential transmission partners }\end{array}$ & $\begin{array}{c}\text { Individuals from } 68 \% \text { of included } \\
\text { countries/regions had potential } \\
\text { transmission partner(s) from another } \\
\text { country/region }\end{array}$ & $\begin{array}{l}\text { The extent of international linkage among HIV } \\
\text { subtypes suggests the need to consider the global } \\
\text { diversity in HIV when describing epidemics }\end{array}$ \\
\hline
\end{tabular}

The articles included in this review discuss the impact of international migration and travel on trends in HIV epidemiology and provide key insights on this relationship. Studies looking at both regional and global transmission are included to demonstrate how HIV moves through populations on different geographic levels.

Several articles discuss the public health consequences of viral importation, exportation, or both. Many of these articles highlight the plausibility of viral importation in triggering HIV epidemics. A phylodynamic study by Rasmussen et al. found that viral introductions into KwaZulu-Natal, a rural region in South Africa, were a major driver of the ongoing epidemic, accounting for an estimated 35\% of new viral infections in the region [40]. These study highlights the role of regional mobility between communities in sustaining HIV epidemics. Expanding to international travel, a study conducted in France assessed the frequency of travel-related illnesses among residents of France who had returned from abroad with an infectious disease [33]. This paper found that of the 265 cases of infections contracted by travelers, six were incident cases of HIV [33]. While this study did not examine transmission after returning to France, there is evidence that travelers can disseminate HIV once they return home $[38,40]$. Such evidence suggests that efforts to control HIV transmission in a region or nation need to account for viral introductions into the region of interest. Knowledge of HIV import will allow jurisdictions to better comprehend the success of their prevention and control methods $[49,50]$ as well as maintaining vigilance to prevent emergence of new outbreaks in areas where HIV is already endemic. Healthcare providers should also consider the possibility of HIV acquisition when evaluating returning international travelers, particularly as people are known to take greater risks when traveling [33].

Human migration also has a key influence on HIV transmission. In a study of HIV across Mesoamerica, human mobility in part due to economic migration likely bridged infected and susceptible populations resulting in transmission of HIV [31]. Wertheim's global look at the overall 
HIV transmission network found many links between persons from different nations, highlighting the role of travel or migration in the spread of the virus [48]. Several studies have also highlighted the onward transmission of non-B HIV-1 subtypes among migrants [45,51]. As non-B HIV-1 is much more likely to have been acquired outside of the US and other western nations, these likely represent easily identified viral introductions crossing international borders [45,51]. Additional evidence for this comes from observations of new viral subtypes [30] and circulating recombinant forms entering certain geographic regions [29]. Others have reported on how migration of infected persons into highly susceptible populations (e.g. injections drug users) can fuel new epidemics [5,36]. It is clear that human mobility and migration are important factors that must be accounted for in order to lower the burden of HIV infection [42] and allow optimization of prevention efforts. Such pathways of viral dissemination warrant intervention strategies that address mobile populations.

Since the virus can be transmitted by a person with HIV (PWH) when traveling, or acquired by a traveler who is engaging in risky behavior, it is evident that dissemination and transmission of HIV is bidirectional [44], indicating that the virus does not discriminate based on direction of movement. Considering the high rate of human mobility at border regions, this would suggest that border populations should be classified as at-risk populations, even if only side of the border has what the WHO considers a generalized epidemic ( $\geq 1.0 \%$ HIV prevalence) [50]. Allocation of resources and prevention efforts directed to border populations and across borders, may have a greater impact than the disbursement of such resources among non-mobile populations. Furthermore, with the constant influx and outflux of new infections into a regional epidemic, there is a need for consistent vigilance of these patterns to keep incidence rates low on all sides of a border. Epidemiological studies have illustrated the possibility of high frequency of extra-community HIV introductions, and suggest that that repeated introductions of HIV play a significant role in sustaining HIV incidence [52]. Some experts suggest that regulation of cross-border travel is necessary to halt the introduction of diseases and infections into regions and ensure minimal risk of an epidemic occurring or expanding [53]. However, such approaches would be nearly impossible to enact in today's age of globalization. Evidence suggests that infection control is optimized when efforts are coordinated across borders [36,46,47], both regional and international.

Without first understanding the dynamics that sustain transmission of HIV, prevention and control efforts can only be limited in effectiveness $[10,44]$. To suppress the HIV epidemic, steep reductions in incidence are critical [14]. Major reductions in incidence have been demonstrated as a result of universal antiretroviral therapy [49]. However, randomized trials demonstrate that implementing such efforts at population levels has shown insignificant differences in HIV incidence [54-56]. The impact of human mobility on such trials is not well understood and may pose a risk for lowering the measured effectiveness of control efforts. To some degree, migration may be acting as an effect modifier. Studies of prevention efforts that do not acknowledge and measure the role of human mobility in HIV and viral migration on outcomes are unlikely to provide accurate results of their impacts. In fact, the influence of mobility and migration may be so significant that the impact of the intervention may be lost [14]. A recent trial found that universal testing in tandem with antiretroviral treatment had the potential to lower HIV incidence, but the authors also recognized that the benefits may be compromised if HIV transmission is concentrated in subgroups [14]. Phylogenetic studies that assess the impact of mobile populations are needed to provide a more explicit understanding of the impact of viral migration on HIV prevention and control efforts.

\section{Conclusions}

The collection of studies presented in this review support coordination of prevention efforts across regional and international borders. While optimal prevention interventions for HIV transmission need to account for behaviors and barriers to care, the goal of population-level reduction and eradication of HIV will only be achieved if the impact of human mobility is properly accounted for in these settings [57]. While the classification of internationally mobile populations as high-risk groups may 
be useful to identifying HIV earlier in these populations, it is important to be aware that mobility occurs regionally as well, and as such care needs to be taken not to stigmatize these populations. Understanding the importance of mobility in a regional epidemic will allow regional HIV prevention programs to better estimate and plan the impact of locally deployed interventions, and help legislators understand the importance of cross-regional coordinated efforts. These need to be balanced with the rights and concerns of migrant populations. Finally, this review highlights that even in the presence of control and preventive efforts, if migration and travel are occurring, public health efforts will need to remain persistent to ensure that new infections do not grow into outbreaks. As Barnett and Whiteside have illustrated in their book AIDS in the Twenty-First Century: Disease and Globalization, "health and wellbeing are international concerns and global goods, and inherent in the epidemic are lessons to be learned regarding collective responsibility for universal human health" [24].

Author Contributions: Conceptualization, E.A.E., S.N.F. and S.R.M.; methodology, E.A.E. and S.N.F.; investigation, E.A.E. and S.N.F.; data curation, E.A.E. and S.N.F.; writing-Original draft preparation, E.A.E., S.N.F., and S.R.M.; writing-Review and editing, E.A.E., S.N.F., and S.R.M.; supervision, S.R.M.; project administration, S.R.M. All authors have read and agreed to the published version of the manuscript.

Funding: This research received no external funding.

Conflicts of Interest: The authors declare no conflict of interest.

\section{References}

1. Komatsu, R.; Sawada, T. The role of international migration in infectious diseases: The HIV epidemic and its trends in Japan. Int. J. Health Serv. 2007, 37, 745-759. [CrossRef] [PubMed]

2. Pybus, O.G.; Tatem, A.J.; Lemey, P. Virus evolution and transmission in an ever more connected world. Proc. Biol. Sci. 2015, 282, 20142878. [CrossRef] [PubMed]

3. Brockmann, D.; Helbing, D. The hidden geometry of complex, network-driven contagion phenomena. Science 2013, 342, 1337-1342. [CrossRef]

4. Soto, S.M. Human migration and infectious diseases. Clin. Microbiol Infect. 2009, 15 (Suppl. 1), 26-28. [CrossRef] [PubMed]

5. Vasylyeva, T.I.; Liulchuk, M.; Friedman, S.R.; Sazonova, I.; Faria, N.R.; Katzourakis, A.; Babii, N.; Scherbinska, A.; Theze, J.; Pybus, O.G.; et al. Molecular epidemiology reveals the role of war in the spread of HIV in Ukraine. Proc. Natl. Acad. Sci. USA 2018, 115, 1051-1056. [CrossRef] [PubMed]

6. Faria, N.R.; Rambaut, A.; Suchard, M.A.; Baele, G.; Bedford, T.; Ward, M.J.; Tatem, A.J.; Sousa, J.D.; Arinaminpathy, N.; Pepin, J.; et al. HIV epidemiology. The early spread and epidemic ignition of HIV-1 in human populations. Science 2014, 346, 56-61. [CrossRef]

7. Beyrer, C. HIV epidemiology update and transmission factors: Risks and risk contexts-16th International AIDS Conference epidemiology plenary. Clin. Infect. Dis. 2007, 44, 981-987. [CrossRef]

8. Faria, N.R.; Vidal, N.; Lourenco, J.; Raghwani, J.; Sigaloff, K.C.E.; Tatem, A.J.; van de Vijver, D.A.M.; Pineda-Pena, A.C.; Rose, R.; Wallis, C.L.; et al. Distinct rates and patterns of spread of the major HIV-1 subtypes in Central and East Africa. PLoS Pathog. 2019, 15, e1007976. [CrossRef]

9. Palk, L.; Gerstoft, J.; Obel, N.; Blower, S. A modeling study of the Danish HIV epidemic in men who have sex with men: Travel, pre-exposure prophylaxis and elimination. Sci. Rep. 2018, 8, 16003. [CrossRef]

10. Rai, T.; Lambert, H.S.; Ward, H. Migration as a risk and a livelihood strategy: HIV across the life course of migrant families in India. Glob. Public Health 2017, 12, 381-395. [CrossRef]

11. McGrath, N.; Eaton, J.W.; Newell, M.L.; Hosegood, V. Migration, sexual behaviour, and HIV risk: A general population cohort in rural South Africa. Lancet HIV 2015, 2, e252-e259. [CrossRef]

12. Coovadia, H.M.; Hadingham, J. HIV/AIDS: Global trends, global funds and delivery bottlenecks. Glob. Health 2005, 1, 13. [CrossRef] [PubMed]

13. UNAIDS. Travel Restrictions. Available online: https://www.unaids.org/en/keywords/travel-restrictions (accessed on 1 October 2019).

14. Hayes, R.J.; Donnell, D.; Floyd, S.; Mandla, N.; Bwalya, J.; Sabapathy, K.; Yang, B.; Phiri, M.; Schaap, A.; Eshleman, S.H.; et al. Effect of Universal Testing and Treatment on HIV Incidence-HPTN 071 (PopART). N. Engl. J. Med. 2019, 381, 207-218. [CrossRef] [PubMed] 
15. CDC. Global Measles Outbreaks. Available online: https://www.cdc.gov/globalhealth/measles/globalmeaslesoutbreaks. htm (accessed on 1 October 2019).

16. Jost, M.; Luzi, D.; Metzler, S.; Miran, B.; Mutsch, M. Measles associated with international travel in the region of the Americas, Australia and Europe, 2001-2013: A systematic review. Travel Med. Infect. Dis. 2015, 13, 10-18. [CrossRef]

17. Bednarczyk, R.A.; Rebolledo, P.A.; Omer, S.B. Assessment of the role of international travel and unauthorized immigration on measles importation to the United States. J. Travel Med. 2016, 23. [CrossRef]

18. Wiratsudakul, A.; Triampo, W.; Laosiritaworn, Y.; Modchang, C. A one-year effective reproduction number of the 2014-2015 Ebola outbreaks in the widespread West African countries and quantitative evaluation of air travel restriction measure. Travel Med. Infect. Dis. 2016, 14, 481-488. [CrossRef]

19. Kohl, K.S.; Philen, R.; Arthur, R.R.; Dott, M.; Avchen, R.N.; Shaw, K.M.; Glover, M.J.; Daley, W.R. United States Notifications of Travelers from Ebola-Affected Countries. Health Secur. 2017, 15, 261-267. [CrossRef]

20. Zhang, X.; Martinez-Donate, A.P.; Simon, N.E.; Hovell, M.F.; Rangel, M.G.; Magis-Rodriguez, C.; Sipan, C.L. Risk behaviours for HIV infection among travelling Mexican migrants: The Mexico-US border as a contextual risk factor. Glob. Public Health 2017, 12, 65-83. [CrossRef]

21. Rachlis, B.; Brouwer, K.C.; Mills, E.J.; Hayes, M.; Kerr, T.; Hogg, R.S. Migration and transmission of blood-borne infections among injection drug users: Understanding the epidemiologic bridge. Drug Alcohol Depend. 2007, 90, 107-119. [CrossRef]

22. Pannetier, J.; Ravalihasy, A.; Lydie, N.; Lert, F.; Desgrees du Lou, A.; Parcours study, G. Prevalence and circumstances of forced sex and post-migration HIV acquisition in sub-Saharan African migrant women in France: An analysis of the ANRS-PARCOURS retrospective population-based study. Lancet Public Health 2018, 3, e16-e23. [CrossRef]

23. Wu, T.; Perrings, C.; Kinzig, A.; Collins, J.P.; Minteer, B.A.; Daszak, P. Economic growth, urbanization, globalization, and the risks of emerging infectious diseases in China: A review. Ambio 2017, 46, 18-29. [CrossRef]

24. Barnett, T.; Whiteside, A. AIDS in the Twenty-First Century: Disease and Globalization, 2nd ed.; Palgrave Macmillan: Basingstoke, UK; New York, NY, USA, 2006; p. 449.

25. Peters, P.J.; Westheimer, E.; Cohen, S.; Hightow-Weidman, L.B.; Moss, N.; Tsoi, B.; Hall, L.; Fann, C.; Daskalakis, D.C.; Beagle, S.; et al. Screening Yield of HIV Antigen/Antibody Combination and Pooled HIV RNA Testing for Acute HIV Infection in a High-Prevalence Population. JAMA 2016, 315, 682-690. [CrossRef] [PubMed]

26. Foundation, K.F. The Global HIV/AIDS Epidemic. Available online: https://www.kff.org/global-healthpolicy/fact-sheet/the-global-hivaids-epidemic/ (accessed on 6 October 2019).

27. Piot, P.; Bartos, M.; Ghys, P.D.; Walker, N.; Schwartlander, B. The global impact of HIV/AIDS. Nature 2001, 410, 968-973. [CrossRef] [PubMed]

28. Mehta, S.R.; Wertheim, J.O.; Brouwer, K.C.; Wagner, K.D.; Chaillon, A.; Strathdee, S.; Patterson, T.L.; Rangel, M.G.; Vargas, M.; Murrell, B.; et al. HIV Transmission Networks in the San Diego-Tijuana Border Region. EBioMedicine 2015, 2, 1456-1463. [CrossRef] [PubMed]

29. Aibekova, L.; Foley, B.; Hortelano, G.; Raees, M.; Abdraimov, S.; Toichuev, R.; Ali, S. Molecular epidemiology of HIV-1 subtype A in former Soviet Union countries. PLoS ONE 2018, 13, e0191891. [CrossRef] [PubMed]

30. Castley, A.; Sawleshwarkar, S.; Varma, R.; Herring, B.; Thapa, K.; Dwyer, D.; Chibo, D.; Nguyen, N.; Hawke, K.; Ratcliff, R.; et al. A national study of the molecular epidemiology of HIV-1 in Australia 2005-2012. PLoS ONE 2017, 12, e0170601. [CrossRef] [PubMed]

31. Chaillon, A.; Avila-Rios, S.; Wertheim, J.O.; Dennis, A.; Garcia-Morales, C.; Tapia-Trejo, D.; Mejia-Villatoro, C.; Pascale, J.M.; Porras-Cortes, G.; Quant-Duran, C.J.; et al. Identification of major routes of HIV transmission throughout Mesoamerica. Infect. Genet. Evol. 2017, 54, 98-107. [CrossRef]

32. de Pina-Araujo, I.I.M.; Delatorre, E.; Guimaraes, M.L.; Morgado, M.G.; Bello, G. Origin and Population Dynamics of a Novel HIV-1 Subtype G Clade Circulating in Cape Verde and Portugal. PLoS ONE 2015, 10, e0127384. [CrossRef]

33. Leroy, H.; Arvieux, C.; Biziragusenyuka, J.; Chapplain, J.M.; Guiguen, C.; Michelet, C.; Tattevin, P. A retrospective study of 230 consecutive patients hospitalized for presumed travel-related illness (2000-2006). Eur. J. Clin. Microbiol. Infect. Dis. 2008, 27, 1137-1140. [CrossRef] 
34. Magiorkinis, G.; Angelis, K.; Mamais, I.; Katzourakis, A.; Hatzakis, A.; Albert, J.; Lawyer, G.; Hamouda, O.; Struck, D.; Vercauteren, J.; et al. The global spread of HIV-1 subtype B epidemic. Infect. Genet. Evol. 2016, 46, 169-179. [CrossRef]

35. Paraskevis, D.; Pybus, O.; Magiorkinis, G.; Hatzakis, A.; Wensing, A.M.; van de Vijver, D.A.; Albert, J.; Angarano, G.; Asjo, B.; Balotta, C.; et al. Tracing the HIV-1 subtype B mobility in Europe: A phylogeographic approach. Retrovirology 2009, 6, 49. [CrossRef] [PubMed]

36. Paraskevis, D.; Kostaki, E.; Nikolopoulos, G.K.; Sypsa, V.; Psichogiou, M.; Del Amo, J.; Hodges-Mameletzis, I.; Paraskeva, D.; Skoutelis, A.; Malliori, M.; et al. Molecular Tracing of the Geographical Origin of Human Immunodeficiency Virus Type 1 Infection and Patterns of Epidemic Spread Among Migrants Who Inject Drugs in Athens. Clin. Infect. Dis. 2017, 65, 2078-2084. [CrossRef] [PubMed]

37. Paraskevis, D.; Beloukas, A.; Stasinos, K.; Pantazis, N.; de Mendoza, C.; Bannert, N.; Meyer, L.; Zangerle, R.; Gill, J.; Prins, M.; et al. HIV-1 molecular transmission clusters in nine European countries and Canada: Association with demographic and clinical factors. BMC Med. 2019, 17, 4. [CrossRef] [PubMed]

38. Parczewski, M.; Urbanska, A.; Grzeszczuk, A.; Maciejewska, K.; Witak-Jedra, M.; Leszczyszyn-Pynka, M. Phylogeographic analysis on the travel-related introduction of HIV-1 non-B subtypes to Northern Poland. Infect. Genet. Evol. 2014, 27, 121-130. [CrossRef]

39. Pieniazek, D.; Baggs, J.; Hu, D.J.; Matar, G.M.; Abdelnoor, A.M.; Mokhbat, J.E.; Uwaydah, M.; Bizri, A.R.; Ramos, A.; Janini, L.M.; et al. Introduction of HIV-2 and multiple HIV-1 subtypes to Lebanon. Emerg. Infect. Dis. 1998, 4, 649-656. [CrossRef] [PubMed]

40. Rasmussen, D.A.; Wilkinson, E.; Vandormael, A.; Tanser, F.; Pillay, D.; Stadler, T.; de Oliveira, T. Tracking external introductions of HIV using phylodynamics reveals a major source of infections in rural KwaZulu-Natal, South Africa. Virus Evol. 2018, 4, vey037. [CrossRef] [PubMed]

41. Schlagenhauf, P.; Weld, L.; Goorhuis, A.; Gautret, P.; Weber, R.; von Sonnenburg, F.; Lopez-Velez, R.; Jensenius, M.; Cramer, J.P.; Field, V.K.; et al. Travel-associated infection presenting in Europe (2008-12): An analysis of EuroTravNet longitudinal, surveillance data, and evaluation of the effect of the pre-travel consultation. Lancet Infect. Dis. 2015, 15, 55-64. [CrossRef]

42. Sinka, K.; Mortimer, J.; Evans, B.; Morgan, D. Impact of the HIV epidemic in sub-Saharan Africa on the pattern of HIV in the UK. AIDS 2003, 17, 1683-1690. [CrossRef]

43. Skar, H.; Axelsson, M.; Berggren, I.; Thalme, A.; Gyllensten, K.; Liitsola, K.; Brummer-Korvenkontio, H.; Kivela, P.; Spangberg, E.; Leitner, T.; et al. Dynamics of two separate but linked HIV-1 CRF01_AE outbreaks among injection drug users in Stockholm, Sweden, and Helsinki, Finland. J. Virol. 2011, 85, 510-518. [CrossRef]

44. Takebe, Y.; Naito, Y.; Raghwani, J.; Fearnhill, E.; Sano, T.; Kusagawa, S.; Mbisa, J.L.; Zhang, H.; Matano, T.; Brown, A.J.; et al. Intercontinental dispersal of HIV-1 subtype B associated with transmission among men who have sex with men in Japan. J. Virol. 2014, 88, 9864-9876. [CrossRef]

45. von Wyl, V.; Kouyos, R.D.; Yerly, S.; Boni, J.; Shah, C.; Burgisser, P.; Klimkait, T.; Weber, R.; Hirschel, B.; Cavassini, M.; et al. The role of migration and domestic transmission in the spread of HIV-1 non-B subtypes in Switzerland. J. Infect. Dis. 2011, 204, 1095-1103. [CrossRef] [PubMed]

46. Wang, X.; Wu, Y.; Mao, L.; Xia, W.; Zhang, W.; Dai, L.; Mehta, S.R.; Wertheim, J.O.; Dong, X.; Zhang, T.; et al. Targeting HIV Prevention Based on Molecular Epidemiology Among Deeply Sampled Subnetworks of Men Who Have Sex With Men. Clin. Infect. Dis. 2015, 61, 1462-1468. [CrossRef] [PubMed]

47. Wang, Y.; Liang, Y.; Feng, Y.; Wang, B.; Li, Y.; Wu, Z.; Zhang, J.; Baloch, Z.; Zhang, A.M.; Liu, L.; et al. HIV-1 prevalence and subtype/recombinant distribution among travelers entering China from Vietnam at the HeKou port in the Yunnan province, China, between 2003 and 2012. J. Med. Virol. 2015, 87, 1500-1509. [CrossRef] [PubMed]

48. Wertheim, J.O.; Leigh Brown, A.J.; Hepler, N.L.; Mehta, S.R.; Richman, D.D.; Smith, D.M.; Kosakovsky Pond, S.L. The global transmission network of HIV-1. J. Infect. Dis. 2014, 209, 304-313. [CrossRef]

49. Cohen, M.S.; Chen, Y.Q.; McCauley, M.; Gamble, T.; Hosseinipour, M.C.; Kumarasamy, N.; Hakim, J.G.; Kumwenda, J.; Grinsztejn, B.; Pilotto, J.H.; et al. Antiretroviral Therapy for the Prevention of HIV-1 Transmission. N. Engl. J. Med. 2016, 375, 830-839. [CrossRef]

50. UNAIDS, W.A. Initiating Second Generation HIV Surveillance Systems: Practical Guidelines; WHO: Geneva, Switzerland, 2002; p. 17. 
51. Wertheim, J.O.; Oster, A.M.; Hernandez, A.L.; Saduvala, N.; Banez Ocfemia, M.C.; Hall, H.I. The International Dimension of the U.S. HIV Transmission Network and Onward Transmission of HIV Recently Imported into the United States. AIDS Res. Hum. Retrovir. 2016, 32, 1046-1053. [CrossRef]

52. Grabowski, M.K.; Lessler, J.; Redd, A.D.; Kagaayi, J.; Laeyendecker, O.; Ndyanabo, A.; Nelson, M.I.; Cummings, D.A.; Bwanika, J.B.; Mueller, A.C.; et al. The role of viral introductions in sustaining community-based HIV epidemics in rural Uganda: Evidence from spatial clustering, phylogenetics, and egocentric transmission models. PLoS Med. 2014, 11, e1001610. [CrossRef]

53. Mouchtouri, V.A.; Lewis, H.C.; Hadjichristodoulou, C.; Partnership, E.S.A.J.A. A Systematic Review for Vaccine-Preventable Diseases on Ships: Evidence for Cross-Border Transmission and for Pre-Employment Immunization Need. Int. J. Environ. Res. Public Health 2019, 16, 2713. [CrossRef] [PubMed]

54. Havlir, D.V.; Balzer, L.B.; Charlebois, E.D.; Clark, T.D.; Kwarisiima, D.; Ayieko, J.; Kabami, J.; Sang, N.; Liegler, T.; Chamie, G.; et al. HIV Testing and Treatment with the Use of a Community Health Approach in Rural Africa. N. Engl. J. Med. 2019, 381, 219-229. [CrossRef]

55. Iwuji, C.C.; Orne-Gliemann, J.; Larmarange, J.; Balestre, E.; Thiebaut, R.; Tanser, F.; Okesola, N.; Makowa, T.; Dreyer, J.; Herbst, K.; et al. Universal test and treat and the HIV epidemic in rural South Africa: A phase 4, open-label, community cluster randomised trial. Lancet HIV 2018, 5, e116-e125. [CrossRef]

56. Makhema, J.; Wirth, K.E.; Pretorius Holme, M.; Gaolathe, T.; Mmalane, M.; Kadima, E.; Chakalisa, U.; Bennett, K.; Leidner, J.; Manyake, K.; et al. Universal Testing, Expanded Treatment, and Incidence of HIV Infection in Botswana. N. Engl. J. Med. 2019, 381, 230-242. [CrossRef] [PubMed]

57. Camlin, C.S.; Cassels, S.; Seeley, J. Bringing population mobility into focus to achieve HIV prevention goals. J. Int. AIDS Soc. 2018, 21 (Suppl. 4), e25136. [CrossRef] [PubMed]

(C) 2020 by the authors. Licensee MDPI, Basel, Switzerland. This article is an open access article distributed under the terms and conditions of the Creative Commons Attribution (CC BY) license (http://creativecommons.org/licenses/by/4.0/). 